\title{
Family Matters: Exploring the Complexities of Families of Immigrant Adolescents and Achievement in Four G8 Countries
}

\author{
Martha J. Strickland ${ }^{1}$ and Lee Shumow ${ }^{*}, 2$ \\ ${ }^{I}$ Behavioral Sciences and Education, The Pennsylvania State University, Harrisburg, USA \\ ${ }^{2}$ Department of Leadership, Educational Psychology \& Foundations, Northern Illinois University, USA
}

\begin{abstract}
This study analyzes the PISA 2003 data to describe the family demographic and educational process characteristics of immigrant adolescents in Canada, France, Germany and the United States of America (USA) and investigates the relationship between family circumstances and the adolescents' educational success. The four countries are among those that receive the most immigrants, have the highest percentage of foreign born among the total population, and where the discrepancy between the immigrant and native students varies dramatically between countries. Adolescent immigrant students within each country were diverse but different patterns were seen in the family characteristics between Canada, the USA and the European countries. Family demographic and educational process characteristics were related to educational achievement of adolescent immigrant students but the associations varied somewhat between countries. Results are discussed in terms of relevance for educational policy, practice, and future research.
\end{abstract}

\section{INTRODUCTION}

Immigration is a significant contemporary global issue. In 2002 the United Nations estimated that there were 175 million persons living outside the country of their birth [1]. Many people immigrate to developed countries to improve the economic circumstances of the family and to provide a better future for their children. Education is a central aspect of children's lives and is crucial to the future economic success of these children and societies [2] yet it is only recently that researchers have focused on the educational success of immigrant children. Families and schools are arguably the major social institutions that shape children's life course trajectories. The current study describes the family characteristics and educational processes of immigrant adolescents in Canada, France, Germany and the USA, countries among those that both receive the most immigrants and have the highest percentage of foreign born among the total population [3], and investigates the relationship between family circumstances and the immigrant adolescents' educational success.

Several international educational studies have included data on the immigration status of study participants. The Programme for International Student Assessment (PISA) 2003 data collected by the Organisation for Economic Cooperation and Development (OECD) is one of those international studies. The PISA data has been gathered from 15year-olds attending an educational institution in several cycles over the past 7 years. Recent work based on the PISA 2003 data took particular note of the educational success of adolescents who reported either being foreign-born or children of at least one foreign-born parent (immigrant). One such OECD analysis of educational outcomes of the PISA 2003 data concluded that, overall, native students in developed

*Address correspondence to this author at the Department of Leadership, Educational Psychology \& Foundations, Northern Illinois University, USA; E-mail:1shumow@niu.edu countries manifest higher academic achievement than immigrant students [4]. Within countries, Stanat and Christensen [4] showed that children of immigrants tended to do equally well on achievement tests when compared to native students in Canada and that the discrepancy between native and immigrant students was largest in several European countries including France and Germany with the USA in between. The authors of the OECD report argue that approaches used to educate immigrant students in Canada may be more effective than in the other countries.

Although educational strategies are important in understanding student achievement, a host of studies have demonstrated that the family is a major contributor to students' educational success [2, 5-9]. However, several studies have reported inconsistent results on whether family characteristics predict achievement among immigrant students [10-12]. Those inconsistencies may be due to the fact that the samples were drawn from different countries, students in each study were of different ages, and achievement was measured differently across studies. For this study we utilize PISA 2003 data to examine family characteristics of immigrant adolescent students in countries that receive a high number of immigrants and investigate how those characteristics are associated with educational outcomes. It is our contention that focusing on just the immigrant adolescents, in contrast to seeking a comparison with the native-born students, will reveal the complexities of profiling educational success within the adolescent immigrant students and in so doing will enrich the present policy discourse as schools seek to facilitate the academic success of this growing population of students within their classrooms.

\section{DEMOGRAPHIC CHARACTERISTICS OF IMMI- GRANT FAMILIES}

Policy makers, scholars and journalists often appear to assume that "immigrants" are a homogenous group in discussions of important educational issues [4, 13, 14]. Bronfenbrenner [15] has discussed this as the "social address" 
approach wherein members of a particular segment of a population are shown to perform better or worse than other segments of a population. One problem with that approach is that, as in any study of groups of people, it is important to understand that there is typically substantial variation within groups. The socioeconomic status (SES) of immigrants in Western developed countries, for example, might vary considerably within countries. Since 1990, there have been historically unparalleled waves of immigrants to developed countries which included adult heads of households with little education and limited workforce skills. At the same time, however, in these same countries, the need for highly educated and skilled scientists, mathematicians, engineers and medical workers has provoked the intentional recruitment of highly educated skilled workers and foreign students pursuing advanced degrees were recruited to enhance their national workforces [16]. This has been particularly notable in Canada's recent immigration trends [17]. In addition, researchers of immigration trends have historically noted the variation of occupational and educational status of immigrants arriving in receiving countries such as the USA [18]. It seems unlikely, then, that immigrants within a country and also across countries, although sharing a common immigration status would also share similar demographic characteristics, especially those that have been associated with educational success such as educational attainment, occupational level, family structure, and bilingualism.

The distributions of immigrants' occupational status and educational level vary between developed countries. Although recent studies note "chronic low-income" among Canadian immigrants, policy changes in the 1990s encouraged highly educated immigrants resulting in an increase in skill and educational level among arriving immigrants [17]. On the other hand, the French adult immigrant population has been reported as predominantly "unskilled" earning low wages [16]. Germany reported that children of recent immigrants had a poverty rate of over $20 \%$ [19]. France has noted an increase in asylum-seekers with low education levels within the past decade. The USA has one of the highest rates of child poverty in the world [20] with more foreign-born than native born living in poverty [21]. These statistics about immigration in the developed countries point to the importance of examining and describing the range and characteristics of immigrant families with school-age children.

Family structure is another important characteristic related to achievement [20]. Children living in single parent homes typically have access to less financial and social capital than children living in households with multiple adults. Single parents are shouldering the burden of family responsibilities alone and might not have as much time to devote to fostering their children's education. Therefore, family structure is considered as potentially relevant to adolescent education in this study.

Linguistic acuity also has been identified as a key contributor to school success and academic achievement. Some scholars argue that discontinuities between conversation patterns at home and school have a negative impact on academic achievement $[22,23]$. Others focus on the effect that speaking a different language at home may have on school achievement because students with limited practice speaking the school language have restricted abilities to understand or express themselves in school. Current research, however, raises questions about that argument. Some researchers have discovered that speaking a different home language than what is spoken in school does not have a negative impact on academic achievement [24]. Bilingualism may offer cognitive advantages. Thus, this study will examine how home language affects academic achievement using the PISA 2003 data on the four identified resettlement countries.

\section{Educational Process Characteristics within Families}

One significant drawback of the social address approach is that members of groups are assumed to share similar psychological and social characteristics yet the proximal processes that promote development are not actually examined and relationships between demographic and educational process characteristics may differ between groups [15]. Few researchers have investigated parenting processes that foster achievement among immigrant parents in representative samples or cross national studies. Several studies have found that immigrant parents have high expectations for their children's educational success [10]. In this study, we were interested in examining indicators of how immigrant families stimulate educational success. Accordingly, we examined the educational resources (e.g. books, computer, and desk) in the home as well as the number of hours students spent out of school on homework and on educationally enriching activities with the understanding that parents are instrumental in organizing and encouraging their children's out of school activities. Fulgini's [25] study of immigrant adolescents in several California (USA) schools found that the immigrant students spent more time on homework compared to native peers. We examine time spent on activities that facilitate educational achievement among a larger cross national immigrant sample.

\section{Relationship Between Family Characteristics and Educa- tional Outcomes}

Finally, we examine associations between measures of educational success and family characteristics within each of the countries. Although we chose variables that have been associated with academic success in the general population or that have been posited as explanations for educational struggles of immigrant children, it is not clear that those variables are associated with educational success among immigrant students. Bronfenbrenner [15] has argued that developmental processes do not necessarily operate similarly across contexts (within population subgroups). Support for that view comes from the well documented connection between socioeconomic status and academic achievement within developed Western countries [11, 12], but it is not clear that SES and achievement are as highly correlated among immigrants as among the general population. For example, a study of young $(<11$ years old) immigrant children in Canada, found that, immigrant students were more resilient to the impact of poverty on academic success than were native children [10]. Another study conducted in several schools in California found small associations between grades of immigrant adolescents and their family social class, generational immigrant status, and predominate home language [25]. Thus, investigating family characteristics and resources outside of SES within adolescent immigrant student populations within these countries is a key focus of this study. 
We found no studies about the relationship between family structure and educational achievement within immigrant families. Since living in a single parent family has been shown to compromise educational success in the general population [26] and since recent research has noted the complex family and care giving constellations of immigrant children [27, 28] the characteristics of the family structure were explored in relation to educational success for this study.

We are cautious about drawing direct comparisons between the countries because each country has different policies for including immigrant populations in their national schooling process. Whereas Canada and the USA provide for all immigrants within their schooling, France and Germany limit the attendance depending upon age of entrance, citizenship of the parents, and language acuity [29]. It is within this complex immigrant landscape that this study attempts to illuminate differences in the population of immigrant adolescent students in developed Western countries and pursues clarity of the impact of immigrant family demographics and educational processes on achievement.

In summary, this study examines three dimensions of family influence on educational success among immigrant students in Canada, France, Germany and the USA, which differ on how well immigrant students perform on educational assessments compared to native students. First we describe family characteristics of adolescent immigrant students within each country. Second we investigate indicators of educational processes within immigrant families in each country and how they are related to demographics. Finally, we examine associations between these family variables and educational achievement of these immigrant students. It is important to consider family factors in studies of children's educational success because families are essential socializing agents within all cultures and should be considered important allies in any programs designed to facilitate the educational success of their children.

\section{METHOD}

\section{Participants}

PISA 2003 provides data from over one-quarter million 15 -year-old students living in one of 30 OECD countries. The desired target population was 15 -year-olds attending an educational institution in one of the OECD countries. This included public, private, and vocational training facilities, to name a few, but it eliminated any workplace or home education facility. In order to obtain as much coverage as possible, the sampling design was a two-stage stratified sample [30]. The first stage involved locating the schools for the sample. This was done using a comprehensive listing of all education institutions in the country which fit the parameters of this study. The second stage involved sampling units within each chosen school. Exclusions were defined as geographically or politically inaccessible schools and students without the language or intellectual skills necessary to successful complete the survey. A school response rate was set at $85 \%$ and a student response rate within each school was set at $80 \%$. The data were weighted to provide for the over-representation of the population using the stratified cluster sampling approach and to provide for the variations of data due to national and local surveying. A final student weight was calculated and utilized in all analyses reported here.
For this study the cases collected from the resettlement countries of the USA, Germany, France, and Canada were selected. These countries were specifically selected because they were: (a) among the countries ranked by OECD as receiving a high numbers of immigrants [3] (b) differed considerably in how immigrant students achieve academically, and (c) collected data on first generation and second generation students. When considering the immigrant adolescent's family structure it is important to note the definition of immigrant being used in this study. In the PISA 2003 database, those adolescents who reported that they were born outside the test country are considered "non-native" and those adolescents who were born inside the test country but had at least one foreign-born parent are considered "first generation." For the purpose of coherence with the literature on immigrant adolescents, the non-native adolescents are identified in this study as "first generation" immigrants and those born in the test country but with at least one foreign-born parent are identified as "second-generation" immigrants. In this study we include both first-generation and second-generation adolescents and exclude all adolescents who reported being born in the test country with parents also from the test country. The resulting sample (weighted $\mathrm{N}$ ) included 58,885 Canadian immigrant students, 102,578 French immigrant students, 124,617 German immigrant students, and 439,534 USA immigrant students.

\section{Procedure}

This present study is a secondary data analysis of the OECD PISA data from the PISA 2003 student self report questionnaire and cognitive skill assessment. The PISA 2003 survey was given to each participant as a 2-hour paper-andpencil testing process. The validity and reliability tests and detailed procedure can be further examined in the PISA 2003 Technical Report [30]. The PISA 2003 student questionnaire collected information pertaining to student characteristics (grade, age, gender); family background (family structure, employment status of parents, occupation of parents, education of parents, home possessions, number of books at home, country of birth for student and parents, and language spoken at home); educational background of student; student reports related to school; student's learning of mathematics; and student's lessons in mathematics.

A cognitive skill assessment was also given to each participant as a paper-and-pencil test. In PISA 2003, mathematics, science, reading, and problem-solving were tested with 85 items taking approximately 210 minutes. Each item was intentionally crafted by national and international researchers to be culturally appropriate utilizing an extensive pilot and testing plan.

\section{Measures}

\section{Family Demographics}

Variables from the PISA 2003 Student Questionnaire file were selected. Parent education (Pared) was solicited in the questionnaire asking the students about the highest educational level attained by each parent. This was then aggregated by the researchers to provide one variable indicating the highest level of education of both parents. Occupational status (Occst) of the father and mother was aggregated to provide a variable describing the highest occupational status in the family. Students reported their mother and father's 
occupation. These were coded as highly skilled white collar, lower skilled white collar, highly skilled blue collar, less skilled blue collar. The family structure variable asked students to describe who usually lived at home with them. Their responses were coded in the data as follows: 1) single-parent family, 2) nuclear family, 3) mixed family, and 4) other combinations not previous mentioned. For the regression analyses this was further recoded into a single parent $=1$ and other $=0$ dummy variable (Singlep). Students' immigrant status (2cndgen) was recoded for this study. Only those who reported being born outside the test country or having parents born outside the test country were considered for this study. Those students who had been born somewhere other than the test country, were considered "first generation" students and those with at least one parent born elsewhere were considered "second generation" students. The foreign language variable, Forlang, $(0=$ assessment language and $1=$ foreign language) also was used.

\section{Family Educational Process}

In the PISA 2003 student questionnaire, students were asked whether their families owned each of eleven different educational resources considered beneficial for fostering academic success. These were: a desk, a place to study, a calculator, a dictionary, a computer, educational software, internet access, literature, poetry, art, and textbooks. A summary variable (Homedres) was created by summing these resources to use in the regression equations. Cronbach's alpha for the scale was .77. Students were also asked about their activities. They were asked how many hours they spent doing homework (Hrshw) and how many hours they spent in out of school lessons each week. The missing data was minimal and eliminated as recommended by the PISA Technical Report [30].

\section{Educational Outcomes}

The achievement scores were merged with the student background data of each individual student for this study. Achievement tests continue to be indicators of academic success and ultimately economic earnings in later years. The achievement data measuring mathematics, reading, and science were utilized for this study.

In light of the complexities associated with such a large educational survey representing a disparate set of countries, school types, and student populations, and translation of items into nationally appropriate forms, the individual student performance raw scores would not be able to be analyzed without accounting for the variances introduced by these differences. Therefore, PISA 2003 data report all achievement data as plausible values as developed by Mislevy and Sheehan based on the imputation theory of Rubin to account for this inevitable variance [30]. Thus five plausible values are included in the PISA 2003 data set for each of the following: reading, mathematics, and science. These intermediate values are best analyzed with the specially designed statistical package, AM Software (air.org). Since students were sampled in entire classrooms, the assumption of independence of observations to maintain unbiased estimators could not be obtained. For the regression procedures a robust variance estimator known as a weighted first-order Taylorseries linearization method is used to correct for any heteroscedasticity of this stratified cluster sampling. The estab- lished plausible values multiple regression analyses using the AM Software statistical package report results in $\mathrm{z}$ scores and $\mathrm{R}^{2}$. The software was used to estimate regression equations in this study using the demographic and family process variables to predict educational performance. The PISA data report contains no missing data of the plausible values reported.

\section{RESULTS}

\section{Demographic Characteristics of Immigrant Families}

The first issue examined in this study pertained to describing the family demographic characteristics of immigrant adolescents attending school. As can be seen in Table 1, the parents of Canadian adolescents have an average educational level of some college and the majority has a parent who is a highly skilled white collar worker. Only twenty percent of Canadian immigrant adolescents reported having a parent who works in a blue collar job. Slightly more than half of Canadian adolescent immigrants spoke a national language in their homes. More (54\%) of the adolescent students were first generation than second.

Table 1. Distribution of Immigrant Adolescents' Family Demographic Characteristics

\begin{tabular}{|l|c|c|c|c|}
\hline & Canada & France & Germany & USA \\
\hline \hline Immigrant Type \\
\hline First Generation & $54 \%$ & $24.4 \%$ & $55.1 \%$ & $42.3 \%$ \\
\hline Second Generation & $46 \%$ & $75.6 \%$ & $44.9 \%$ & $57.7 \%$ \\
\hline Parent Occupational Status \\
\hline White Collar Highly Skilled & $59.6 \%$ & $30.7 \%$ & $28.7 \%$ & $58.4 \%$ \\
\hline White Collar Less Skilled & $20.4 \%$ & $20.5 \%$ & $26.5 \%$ & $21.4 \%$ \\
\hline Blue Collar Highly Skilled & $8.7 \%$ & $25.6 \%$ & $24.3 \%$ & $10.7 \%$ \\
\hline Blue Collar Less Skilled & $11.3 \%$ & $23.2 \%$ & $20.5 \%$ & $9.5 \%$ \\
\hline Parent Education & $14.8(2.8)$ & $9.4(4.9)$ & $8.8(6.6)$ & $12.0(4.9)$ \\
\hline Years of Education & $50.2 \%$ & $60.4 \%$ & 52.8 & $42.8 \%$ \\
\hline Home Language & $49.8 \%$ & $39.6 \%$ & 47.2 & $57.2 \%$ \\
\hline Test/National Language & $7.4 \%$ & $6.2 \%$ & $3.7 \%$ & $9.9 \%$ \\
\hline Foreign Language & $16.8 \%$ & $20.8 \%$ & $12.3 \%$ & $28.6 \%$ \\
\hline Family Structure & $75.8 \%$ & $73.0 \%$ & $84.0 \%$ & $61.6 \%$ \\
\hline Single-parent & \multicolumn{5}{|l|}{} \\
\hline Nuclear family & \multicolumn{5}{|l|}{} \\
\hline Other & \multicolumn{5}{|l|}{} \\
\hline
\end{tabular}

Turning to France, we see that the average level of education for the French adolescent students' parents is 9.4 years and that nearly half are blue collar workers. Approximately $3 / 4 \mathrm{~s}$ of the French students live in nuclear families. French immigrant adolescent students are far more likely to be second generation and most (62.4\%) speak French at home.

In Germany, the average parent of the immigrant adolescents had only 8.8 years of schooling, yet the variance as 
indicated by the standard deviation is considerable. Parents' occupational status is distributed quite evenly across economic groups and the vast majority of students live in nuclear families. Slightly more than half of these students live in families that speak German. Less than half are second generation. Parents of the adolescent immigrant students in the USA have an average of 12 years of education and the vast majority work in white collar jobs. Most (57.3\%) speak a foreign language at home and are second generation $(57.7 \%)$. More than a quarter live in single parent families.

The demographic characteristics of first and second generation immigrant students also were calculated. The pattern is similar between first and generation students within each country so we do not present family characteristics by generational status here.

\section{Educational Processes}

Table 2 displays the percentage of 15 -year-old students in each country who have particular educational resources available to them. As can be seen in the table, an overwhelming majority of Canadian adolescent immigrant students have basic educational resources (e.g. desk, place to study, calculator, and dictionary) available to them in their homes. Almost all of them also have a computer with internet access, but fewer (approximately two-thirds) of them have educational software. Nearly two-thirds have art and more than three quarters of them have textbooks, but less than half have literature and poetry. The Canadian immigrant students do more than one hour of homework per day and participate in lessons outside of school less than an hour per week.

Almost all French adolescent immigrant students also have basic educational resources but only about two thirds have computers, less than half have internet access, and slightly more than one-third have educational software. Interestingly, textbooks are available in more of their homes than in the homes of any other country. Art is atypical yet more than half have literature and some (more than onethird) have poetry. Adolescent immigrant students in France do homework about one hour per day and spend an average of twenty minutes per week in out of school lessons.

Like their peers, the vast majority of German adolescent immigrant students have access to basic educational resources. Many ( $85 \%)$ also have a computer at home; nearly half have educational software and a bit more than half have home internet access. In terms of reading material less than a quarter have literature but half have poetry and approximately three quarters have textbooks. German adolescents spend a little less than an hour doing homework and very little time in out of school lessons.

USA students tend to have calculators and a dictionary at home but nearly one-fifth do not have a desk and one-quarter report not having a place to study. As many have a computer as have a desk. Nearly three quarters have home internet access and more than half have educational software. Only about one-third have literature and poetry but nearly three quarters have textbooks at home. Almost half have art in their homes. They spend a little less than an hour per day doing homework and average 40 minutes weekly in out of school lessons.

Correlations between the family demographic and educational processes variables within each country are displayed in Tables 3 and 4. Not surprisingly, examination of these associations reveals that the parents' educational level is associated positively with occupational level and with how many hours adolescents spend doing homework, as well as

Table 2. Educational Process Characteristics in Immigrant Families Across Countries

\begin{tabular}{|c|c|c|c|c|c|}
\hline \multicolumn{5}{|l|}{ Home Educ Resources } & Chi Square \\
\hline Place Study & $89.2 \%$ & $85.5 \%$ & $88.7 \%$ & $77.7 \%$ & $11,941^{* * *}$ \\
\hline Calculator & $98.5 \%$ & $96.1 \%$ & $97.4 \%$ & $90.6 \%$ & $12,055^{* * *}$ \\
\hline Computer & $96.0 \%$ & $68.3 \%$ & $84.7 \%$ & $81.5 \%$ & $20,836^{* * *}$ \\
\hline Educational Software & $68.3 \%$ & $36.4 \%$ & $47.0 \%$ & $53.2 \%$ & $17,475^{* * *}$ \\
\hline Internet & $93.4 \%$ & $45.4 \%$ & $56.0 \%$ & $72.9 \%$ & $54,562 * * *$ \\
\hline Literature & $45.3 \%$ & $58.4 \%$ & $22.0 \%$ & $35.9 \%$ & $33,890 * * *$ \\
\hline Textbooks & & & & & ANOVA F \\
\hline Summary Variable Mean N & $8.7(1.9)$ & $7.3(2.2)$ & $7.6(2.2)$ & $7.4(2.7)$ & $5,042 * * *$ \\
\hline Hours of Homework & $8.4(6.6)$ & $7.2(5.8)$ & $6.4(4.9)$ & $6.5(6.1)$ & $1,769 * * *$ \\
\hline Hours Out of school lessons & $.88(2.0)$ & $0.35(1.1)$ & $0.20(1.2)$ & $.61(1.6)$ & $2,817 * * *$ \\
\hline
\end{tabular}

$* * * \mathrm{p}<.001$

Note: The out of school lessons variable has very high variance within each country indicating that the variable is skewed. 
Table 3. Correlations Between Family Demographic and Educational Process Variables in Canada and the USA

\begin{tabular}{|c|c|c|c|c|c|c|c|}
\hline & 1 & 2 & 3 & 4 & 5 & 6 & 7 \\
\hline 1. Pared & --- & $.38 * * *$ & $-.05 * * *$ & $.04 * * *$ & $.14 * * *$ & $.10 * * *$ & $.25 * * *$ \\
\hline 2. Occst & $.41 * * *$ & --- & $.03 * * *$ & $.10 * * *$ & $-.08 * * *$ & $.07 * * *$ & $.23 * * *$ \\
\hline 3. Singlep & $.01 * * *$ & $.06 * * *$ & --- & $-.05^{* * *}$ & .00 & $-.26 * * *$ & $-.10 * * *$ \\
\hline 4. Forlang & $-.23^{* * *}$ & $-.26 * * *$ & $-.06 * * *$ & --- & $-.36^{* * *}$ & $.07 * * *$ & $-.01 * *$ \\
\hline 5. $2 \mathrm{cndgen}$ & $-.02 * * *$ & $.03 * * *$ & $-.11 * * *$ & $-.24 * * *$ & --- & $-.08 * * *$ & $-.06 * * *$ \\
\hline 6. Hrshw & $.21 * * *$ & $.15^{* * *}$ & $-.01 * * *$ & $-.07 * * *$ & $-.01 * * *$ & --- & $.16^{* * *}$ \\
\hline 7. Homeedres & $.40 * * *$ & $.32 * * *$ & $-.15 * * *$ & $-.20 * * *$ & $.05 * * *$ & $.32 * * *$ & --- \\
\hline
\end{tabular}

Note. Canada above diagonal and USA below. 1 . Pared $=$ parent education; 2 . Occst $=$ parent occupational status; 3 . Singlep $=$ single parent family; 4 . Forlang $=$ foreign language spoken at home: $5.2 \mathrm{cndgen}=$ Second generation immigration status; $6 . \mathrm{Hrshw}=$ hours of homework; 7 . Homedres $=$ home educational resources.

Table 4. Correlations Between Family Demographic and Educational Process Variables in Canada and the USA

\begin{tabular}{|c|c|c|c|c|c|c|c|}
\hline & 1 & 2 & 3 & 4 & 5 & 6 & 7 \\
\hline 1. Pared & --- & $.47 * * *$ & $.01 * * *$ & $-.24 * *$ & $-.04 * *$ & $.13 * * *$ & $.33 * * *$ \\
\hline 2. Occst & $.27 * * *$ & --- & $-.05 * * *$ & $-.22 * * *$ & $-.06 * * *$ & $.03 * * *$ & $.35 * * *$ \\
\hline 3. Singlep & $.08 * * *$ & $-.07 * * *$ & --- & $-.08 * * *$ & $-.01 * * *$ & .00 & $-.08 * * *$ \\
\hline 4. Forlang & $-.12 * * *$ & $-.05^{* * *}$ & $.02 * * *$ & --- & $.15^{* * *}$ & $-.11 * * *$ & $-.19 * * *$ \\
\hline 5. $2 \mathrm{cndgen}$ & $.03 * * *$ & $-.04 * * *$ & $-.01 * * *$ & $-.04 * * *$ & --- & $.10 * * *$ & $.10 * * *$ \\
\hline 6. Hrhw & $.08 * * *$ & $.09 * * *$ & .00 & $-.10 * * *$ & $.05^{* * *}$ & --- & $.24 * *$ \\
\hline 7. Homedres & $.20 * * *$ & $.21 * * *$ & $-.04 * * *$ & $-.13 * * *$ & $.02 * * *$ & $.14 * * *$ & --- \\
\hline
\end{tabular}

Note: France above the diagonal and Germany below. 1. Pared = parent education; 2 . Occst = parent occupational status; 3 . Singlep = single parent family; 4 . Forlang = foreign language spoken at home: $5.2 \mathrm{cndgen}=$ Second generation immigration status; 6 . Hrshw = hours of homework; 7 . Homedres $=$ home educational resources.

with home educational resources in each of the countries even though the magnitudes of the associations differ between countries. Parents' educational level is associated positively with speaking a foreign language at home in Canada but negatively in the other three countries. In every country, except Canada, speaking a foreign language at home was associated negatively with hours spent doing homework. The pattern of associations between generational status and other variables differed within each country.

\section{Relationship Between Family Characteristics and Educa- tional Achievement}

AM statistical software [31] was used to estimate multiple regression equations. AM provides $\mathrm{R}$ squares which describe the proportion of the variance explained by the variables in the equation and also tests the significance of the contribution of each variable by using $\mathrm{z}$ scores. AM uses Wald statistics to test significance which together with student weight adjust for over-representations of groups within the stratified cluster sampling. Two sets of regression equations were estimated for each outcome in each country. The first equation uses the family demographic variables to predict plausible values and the second adds the family educational process variables to the equation.

Table 5 displays the results of the equations predicting reading. Each equation explains a significant amount of the variance and there is a substantial increase in the variance explained after adding the educational process variables.
Looking at similar equations, the percent of variance explained differs by as much as $15 \%$ across countries. Turning to examination of the specific variables, each demographic characteristic predicts reading in both Canada and the USA such that parent education and occupational status are associated positively whereas single parent family structure, speaking a foreign language at home, and second generation status are associated negatively with reading achievement. In France and Germany, however, living in a single parent family and being second generation are not related to reading nor is speaking a foreign language at home in France. The educational process variables are related to reading in each country and appear to mediate the relationship between parent education and reading as indicated by the decrease and insignificance of the parent education $\mathrm{z}$ scores after adding the process variables [32].

The associations between family characteristics and mathematics performance are displayed in Table 6. As with reading, each equation explains a significant amount of variance yet the percent of variance explained by the variables within each country differs by as much as $18 \%$. In Canada, although parent education, occupational status, being second generation, having resources and doing more homework are each associated with mathematics performance, the family characteristics explain a relatively small amount of the variance for the Canadian sample for whom speaking a foreign language does not appear to be a detriment for learning mathematics. The mathematics performance of students in the French sample is associated with parent educational 
Table 5. Family Characteristics Predicting Reading Performance

\begin{tabular}{|c|c|c|c|c|c|c|c|c|}
\hline & \multicolumn{2}{|c|}{ Canada } & \multicolumn{2}{c|}{ France } & \multicolumn{2}{c|}{ Germany } & \multicolumn{2}{c|}{ USA } \\
\hline \hline Pared & $2.30^{*}$ & 0.65 & $4.29^{* * *}$ & 1.88 & $.89^{* * *}$ & .853 & $2.68^{* * *}$ & 0.625 \\
\hline Occst & $3.27^{* * *}$ & $2.16^{*}$ & $2.43^{*}$ & $2.05^{*}$ & $4.72^{* * *}$ & $4.20^{* * *}$ & $2.54 * * *$ & 1.331 \\
\hline Singlep & $-2.86^{* *}$ & -1.87 & -1.68 & -0.98 & -1.19 & -0.56 & $-4.14 * * *$ & $-3.70^{* * *}$ \\
\hline Forlang & $-3.38^{* * *}$ & $-3.68^{* * *}$ & -1.43 & -0.81 & $-4.44^{* * *}$ & $-4.05^{* * *}$ & $-3.21^{* * *}$ & $-2.48^{*}$ \\
\hline 2cndgen & $-5.14^{* * *}$ & $-4.52^{* * *}$ & -1.60 & -0.87 & 1.01 & 1.65 & $-2.33^{* *}$ & $-2.04^{*}$ \\
\hline Homedres & & $6.86^{* * *}$ & & $6.98^{* * *}$ & & $3.19^{* * *}$ & & $4.10^{* * *}$ \\
\hline Hrshw & & $5.87^{* * *}$ & & $3.92^{* * *}$ & & $2.32^{*}$ & & $6.03^{* * *}$ \\
\hline & & & & & & & .221 & .141 \\
\hline R Squared & .072 & .154 & .163 & .300 & .161 & & .289 \\
\hline
\end{tabular}

Note. 1 . Pared $=$ parent education; 2 . Occst $=$ parent occupational status; 3 . Singlep $=$ single parent family; 4 . Forlang $=$ foreign language spoken at home: $5.2 \mathrm{cndgen}=$ Secon generation immigration status; 6 . Hrshw $=$ hours of homework; 7 . Homedres $=$ home educational resources

$* \mathrm{p}<.05, * * \mathrm{p}<.01, * * * \mathrm{p}<.001$.

level, occupational status, and home educational resources but not with homework, generational status or living in a single parent family. Similarly, homework is not associated with mathematics for German students. In the German sample, parent education also is not associated with mathematics performance although occupational status, speaking German at home, being first generation, and having educational resources are. Among immigrant students in the USA doing more homework is strongly associated with mathematics performance. Furthermore, the educational process variables appear to mediate the association between parent education and occupational status in the USA sample. Living in a single parent family and speaking a foreign language at home is associated negatively and generational status is not associated with mathematics performance. Thus, very different patterns of family influence are seen across countries.

The associations between family characteristics and science performance are displayed in Table 7. As was noted with reading and math, most of the equations explain a significant amount of variance, yet it is important to note two important variations; one within each country and one across countries. Within countries, Canada stands out as $6 \%$ of the variance is explained by the demographic factors but when family educational processes are added to the equation $23 \%$ of the variance in science performance is explained. The family educational resources and the hours of homework mediate the single parent and to some extent the parent education and immigrant status predictors. In France, although family educational processes add to the variance, neither single parent, immigrant status and foreign language in the home significantly predicts science performance. On the other hand, speaking a foreign language at home predicts science achievement negatively in the other countries. In the USA, the relationship between parental occupational status and achievement is mediated by educational processes. Generational status is related to science performance only in Germany. In addition, it must be noted that the single parent home only significantly predicts science performance in the USA.

\section{DISCUSSION}

We began this study with the goal of examining the family characteristics of adolescent immigrant students in four highly developed countries that have very different profiles of educational success among adolescent immigrant students compared to native populations. Some scholars have argued that those differences are attributable to school factors in those countries. We agree that school factors contribute to educational attainment, but families are also important to

Table 6. Family Characteristics Predicting Mathematics Performance

\begin{tabular}{|c|c|c|c|c|c|c|c|c|}
\hline & \multicolumn{2}{|c|}{ Canada } & \multicolumn{2}{c|}{ France } & \multicolumn{2}{c|}{ Germany } & \multicolumn{2}{c|}{ USA } \\
\hline \hline Pared & $3.37^{* * *}$ & $2.21^{*}$ & $4.35^{* * *}$ & $2.01^{*}$ & .86 & .81 & $3.00^{* *}$ & 1.89 \\
\hline Occst & $4.51^{* * *}$ & $3.80^{* * *}$ & $3.15^{* *}$ & $2.56^{* *}$ & $5.36^{* * *}$ & $4.92^{* * *}$ & $2.71^{* *}$ & 1.47 \\
\hline Singlep & $-2.03^{*}$ & -1.15 & -1.33 & -0.75 & -1.26 & -0.82 & $-3.95^{* * *}$ & $-3.38^{* * *}$ \\
\hline Forlang & -.55 & -0.54 & $-.77^{*}$ & -0.07 & $-4.00^{* * *}$ & $-3.50^{* * *}$ & $-2.92^{* *}$ & $-2.64 * *$ \\
\hline 2cndgen & $-2.31^{* * *}$ & $-2.44^{*}$ & -1.40 & -1.18 & $1.96^{*}$ & $2.46^{*}$ & -.67 & -0.53 \\
\hline Homedres & & $4.68^{* * *}$ & & $5.95^{* * *}$ & & $2.90^{* *}$ & & $2.66^{* *}$ \\
\hline Hrshw & & $3.87^{* * *}$ & & 1.70 & & 1.02 & .187 & .134 \\
\hline R Squared & .053 & .088 & .143 & .227 & .145 & $.144^{* * *}$ \\
\hline
\end{tabular}

Note. 1. Pared = parent education; 2 . Occst $=$ parent occupational status; 3 . Singlep $=$ single parent family; 4. Forlang $=$ foreign language spoken at home: 5 . $2 \mathrm{cndgen}=$ Second generation immigration status; 6 . Hrshw $=$ hours of homework; 7 . Homedres $=$ home educational resources. $* \mathrm{p}<.05, * * \mathrm{p}<.01, * * * \mathrm{p}<.001$. 
Table 7. Family Characteristics Predicting Science Performance

\begin{tabular}{|c|c|c|c|c|c|c|c|c|}
\hline \multirow[b]{2}{*}{ Pared } & \multicolumn{2}{|c|}{ Canada } & \multicolumn{2}{|c|}{ France } & \multicolumn{2}{|c|}{ Germany } & \multicolumn{2}{|c|}{ USA } \\
\hline & $3.07 * *$ & $2.45^{*}$ & $3.17 * *$ & 1.10 & 0.98 & 1.10 & $2.29 * *$ & 0.78 \\
\hline Occst & $3.53 * * *$ & $3.89^{* * *}$ & $3.21 * * *$ & $2.36^{*}$ & $6.10^{* * *}$ & $5.67 * * *$ & $2.46^{*}$ & 1.59 \\
\hline Singlep & $-2.80 * *$ & $-2.87^{* *}$ & -1.67 & -1.35 & -0.67 & 0.03 & $-4.01 * * *$ & $-3.03 * *$ \\
\hline Forlang & $-3.24 * * *$ & $-3.27 * * *$ & -.89 & -0.15 & $-3.94 * * *$ & $-3.46^{* * *}$ & $-3.09^{* *}$ & $-2.12 *$ \\
\hline 2cndgen & -1.94 & 0.89 & -1.51 & -1.10 & $2.20^{* *}$ & $3.31 * * *$ & 0.53 & 0.41 \\
\hline Homedres & $\mathrm{x}$ & $6.09 * * *$ & $\mathrm{x}$ & $5.76^{* * *}$ & $\mathrm{x}$ & $2.81 * *$ & $\mathrm{x}$ & $4.11^{* * *}$ \\
\hline Hrshw & $\mathrm{x}$ & $5.14 * * *$ & $\mathrm{x}$ & $2.33 *$ & $\mathrm{x}$ & 1.78 & $\mathrm{x}$ & $3.97 * * *$ \\
\hline R Squared & .065 & .227 & .123 & .253 & .179 & .225 & .124 & .249 \\
\hline
\end{tabular}

Note. 1 . Pared $=$ parent education; 2 . Occst $=$ parent occupational status; 3 . Singlep $=$ single parent family; 4 . Forlang $=$ foreign language spoken at home: $5.2 \mathrm{cndgen}=$ Second generation immigration status; 6 . Hrshw $=$ hours of homework; 7 . Homedres $=$ home educational resources.

$* \mathrm{p}<.05, * * \mathrm{p}<.01, * * * \mathrm{p}<.001$

facilitating school success and we set out to investigate family characteristics that have been shown to contribute to educational achievement in general population studies.

Immigrants are sometimes referred to as though they form a monolithic group. We suspected that adolescent immigrant students within highly developed countries live within a complex landscape rather than at similar social addresses. Consistent with Bronfenbrenner's ideas, our findings clearly illustrate that adolescent immigrant students constitute a heterogeneous group within each country. There is a range of parental education and occupational status within the students' families. Some speak the national language and others speak a foreign language at home. Most live in traditional nuclear families but a minority lives in single parent or extended families. It is important for educators, policy makers and the public to recognize the diversity within the population of immigrant students.

It must, however, be noted that the demographic pattern of adolescent immigrants families differs between four developed countries with large immigrant population. Canada, the country cited as having no differences between the achievement of immigrant and native adolescents, has adolescent immigrant students living with highly educated parents with relatively high occupational status. On the other hand, in France and Germany, where there is a huge disparity between immigrant and native students, few immigrant students came from families with substantial educational resources. It is important to point out that the French and German data underestimate the situation of adolescents who are immigrants in those countries because only students were sampled by the PISA 2003 data collection. It was only in recent years that foreign-born adolescents were given the same rights to education as the citizens of France. In addition, immigration flows into France have been small compared to Germany as their immigration policies in the past decade have shifted providing for only asylum seekers [33]. In Germany, as in many European countries, although the educational system is considered open for all, the language acuity requirement for the secondary students keeps out many immigrants [33].

It must be noted that this study did not include ethnicity, which is an important aspect of the immigrant experience [34], because data collection on this variable was inconsis- tent across countries. Future studies will need to examine the patterns and associations of immigrant students' ethnic backgrounds with their educational trajectories.

Our findings show some clear associations between family characteristics and educational success among immigrant populations. Judging from the variance accounted for and comparing them to the pattern of findings in numerous other general population studies, although significant, those associations and effect sizes are not as strong for demographic characteristics as they are in the general population. Given studies that show that immigrants with low socioeconomic status hold high aspirations for their children's educational success [10], immigrants with less education and occupational status might value education and consequently socialize their children to work hard and succeed in school more than do native parents of similar socioeconomic level. The educational process characteristics were strong contributors to achievement in most cases. This is good news because those characteristics are more amenable to intervention than demographic characteristics.

Different patterns of association between family characteristics and achievement were evident between countries. A recently released report concerning immigrant students' success as revealed in the PISA 2003 data grounded their discussion of variance between countries in the variation of institutional policies and services offered to the foreign-born students and the different approaches to language learning in the school settings [30]. Our study, however, exposed another issue which calls for attention. This issue is that first and second generational status was not significant when predicting immigrant students' educational success. This suggests that schools should not overlook the native-born students of immigrant parents in their efforts to facilitate increased achievement among immigrant students.

We believe that the large sample size, attention to weighting, and number of countries in the PISA study provide unique opportunities to advance knowledge but remind the readers of several limitations related to the nature of the data. First, as in all correlational studies, it is important to remember that correlation does not imply causation and we have taken care not to claim causation in our description of the findings. Second, the data is cross sectional. Future studies that follow the educational trajectories of immigrant stu- 
dents longitudinally would greatly enhance our knowledge about how these students and their families adapt to schools in their receiving countries. Third, several of our measures were restricted by the fact that there were a limited number of items in the data set. This is often a problem with secondary analysis of a large data set. Fourth, the demographic and educational process measures are further limited by the well known restrictions of self report data. Finally, we conducted a substantial number of statistical tests which increases the danger of making Type One errors. Readers should be especially careful, then, about over interpreting those few significant findings at the .05 level. The chance of making Type One errors are substantially reduced among those associations with higher $\mathrm{p}$ values.

Despite the limitations, these findings suggest several implications for policy. For one, receiving countries should be careful not to make one size fits all policy for educational programs serving immigrant students. Educational policies and services instituted on a national or local level to address the needs of immigrant students often focus on instructional strategies and language learning. Families are rarely mentioned as partners. What we have found here is that when considering the academic performance of immigrant students, family matters. The family's investment in supplying educational resources for their children and establishing a climate where homework is expected significantly predicts the students' academic achievement. These results suggest that it is wise for the school to include venues for communicating with parents about homework and information for these foreign-born parents about the value of home educational resources to academic achievement. Schools can encourage families to use computers at and borrow books and other educational resources from public libraries.

Secondly, although schools tend to provide focus on language learning as the key service to these students, the student's home language was not the most powerful contributor to the students' academic achievement. Speaking a foreign language at home tended to be more strongly associated with achievement in the USA than the other countries. This might be because numerous immigrant students in the USA are estimated not to have an English speaker in their home [35], which hinders communication between home and school. Nevertheless, there are many additional potentially productive approaches schools could use to assist immigrant students. The present issue of which languages are utilized by schools is very much foregrounded within the contemporary global education discourse [33]. The place of language as a symbol of national identity and the school's role in fostering this needs to be examined. The reliance on teaching the native language to the exclusion of focusing on resourcing the families with educational tools such as books and computers needs to be evaluated carefully in future studies.

Third, educational policy within nations should be based on empirical findings about the diversity of the immigrant population and the value of family involvement within immigrant populations. A report about the No Child Left Behind (NCLB) act, a central educational policy document in the USA, identified increased parental involvement as a priority to increase the academic success of immigrant students [36]. Nationally representative studies need to examine associations between parent involvement and educational success taking into account the diversity of the immigrant student population. It is likely that the success of parent involvement strategies will depend on how aligned they are with cultural practices and beliefs. Unfortunately, we could not examine more about parent involvement. The PISA 2003 data did not collect information on some potentially important family processes such as parental monitoring of the adolescent, parent school communication, or parent attendance at school events or conferences.

Some programs that address educational needs of immigrants have focused on first generation, especially newcomer, students. This study reveals small associations of generational status on demographic or educational process variables and few associations between generational status and educational achievement. These findings support the inclusion of second generation students in the definition of "immigrant" and suggest that children should be chosen for programs based on their needs rather than on where they were born.

An advantage of this study is the use of a large cross international data set weighted to provide national representation. Most previous studies of family influence on immigrant students has come from local samples within one country [28]. In addition, the majority of the studies center on comparing achievement between countries. This study seeks to point out the importance of considering each country's unique characteristics within their immigrant families with adolescent students in school.

As in all secondary analyses of large data sets, however, there were several limitations. Several of those have been aforementioned. Another limitation is that the measure of educational success did not include grades or school orientation (behavior/work habits) variables. Grades are a strong predictor of how much education a student will eventually attain [34] and work habits also are important contributors to success.

\section{CONCLUSION}

As ethnographic researchers have studied immigrants around the world, they have elegantly described the complexities of immigrants' lives and highlighted variation between families as they navigate school and work spaces but unfortunately few of those studies are included in the conversation regarding educational success or school achievement. This study provides empirical evidence of the variations among immigrant families and suggests that more attention should be focused on that variation in discussions about the education of immigrant students. Our study suggests that providing educational resources to families can enhance their opportunity for educational success. It is our contention that a reframing of how schools and educational policy makers look at immigrants, particularly recognizing the "family matters," is the first step to facilitating educational success within our growing immigrant populations worldwide. As the global flow of immigration continues to challenge schools around the world we propose that we turn our attention away from the "lamentable choir" that problematizes the immigrant population as a whole and begin to address issues, such as family educational resources, with the goal to "maximize its [immigration] contribution to the country and communities that it creates" [60]. 


\section{REFERENCES}

[1] International Migration Report. International Migration: A global issue for the twenty-first century. New York: United Nations 2000.

[2] Woessman L. How Equal Are Educational Opportunities? Family Background and Student Achievement in Europe and the United States, 2004; CESIFO WORKING PAPER NO. 1162 [cited 2008 February 25]. Available from: http://www.cesifogroup.de

[3] Dumont JC, Lamaitre G. Counting immigrants and expatriates in OCED countries: A new perspective. Report of the Fourth Coordination Meeting on International Migration of the Organization for Economic Co-operation and Development OECD. In Trends in International Migration. 2005; New York: United National Secretariat [cited 2006 April 13]. Available from: http://www.oecd.org/ dataoecd/34/59/3504 3046.pdf

[4] Stanat P, Christensen G. Where immigrant students succeed: A comparative review of performance and engagement in PISA 2003. Organization for Economic Co-operation and Development (OECD). 2006 [cited 2008 February 25]. Available from: http://www.oecd.org/dataoecd/2/38/36664934.pdf

[5] Chiu MM, Khoo L. Effects of resources, inequality and privilege bias on achievement: Country, school, and student level analyses. Am Educ Res J 2005; 42(4): 575-603.

[6] Hanushek EA. Publicly Provided Education. In Auerbach AJ, Feldstein M, Eds. Handbook of Public Economics. Amsterdam: Elsevier 2002; 2: 2045-141

[7] Henderson, AT, Mapp KL. A new wave of evidence: The impact of school, family, and community connections on student achievement. Austin, TX: Southwest Educational Development Laboratory, 2002.

[8] Jeynes W. A Meta-Analysis: The Effects of Parental Involvement on Minority Children's Academic Achievement. Educ Urban Soc 2003; 35(2): 202-18

[9] Jeynes W. The Relationship Between Parental Involvement and Urban Secondary School Student Academic Achievement: A MetaAnalysis. Urban Educ 2007; 42(1): 82-110.

[10] Georgiades K, Boyle M, Duku E. Contextual influences on children's mental health and school performance: The moderating effects of family immigrant status. Child Dev 2007; 78(5): 1572-91.

[11] Mullis IVX, Marin MO, Gonzalez EJ, et al. TIMSS 1999 international mathematics report : Findings from IEA's repeat of the Third International Mathematics and Science Study at the eighth grade. Chestnut Hill, MA: Boston College, 2000.

[12] Sen A, Partelow LA, Miller DC. Comparative indicators of education in the United States and other G8 countries (2004) [Electronic Version] (Report No. NCES 2005-021). Washington, DC: National Center for Education Statistics, February 2005.

[13] Berger J. Immigrant Children Shielded From State Tests, but for Whose Protection? December 27, 2006; New York Times [cited 2008 March 13]. Available from: http://www.nytimes.com

[14] Freedman S. School Records on Special English Classes Are Called Works of Fiction by Critics. New York Times. April 11, 2007 [cited 2008 March 13]. Available from: http://www.nytimes.com

[15] Bronfenbrenner U. Making Human Beings Human: Bioecological Perspectives on Human Development; Thousand Oaks CA: Sage, 2004.

[16] Hegen D. Recent immigration developments in Germany and France. Washington, DC: National Conference of State Legislatures. Ocotber 2001 [cited 2006 April 15]. Available from: http://www.ncsl.org/programs/ immig/publications.htm
[17] Pico WG, Hou F, Coulombe S. Chronic low income and lowincome dynamics among recent immigrants. 2007: Available from: http://www.statcan.ca/English/research

[18] De Jong GF, Blair MC. Changing occupational characteristics of USA immigrants. Asian Pac Migr J 1994; 3(4): 567-88.

[19] United Nations Children's Fund (UNICEF). Child poverty in rich countries. The proportion of children living in poverty has risen in a majority of the world's developed economies. Innocenti Report Card No. 6. Florence, Italy: UNICEF Innocenti Research Centre, 2005

[20] Kamerman SB, Neuman M, Waldfogel J, Brooks-Gunn J. Social policies, family types and child outcomes in selected OECD countries. OECD Social, Employment and Migration Working Papers, Paris, France: OECD, 2003.

[21] Grieco E. Characteristics of foreign born in the United States: Result from Census 2000. In Migration Information Source, December 1, 2002; Migration Policy Institute. Available from: www.migrationinfor mation.org/USFocus.

[22] Heath SB. Ways with Words. England: Cambridge University Press, 1983.

[23] Tharp RG, Gallimore, R. Rousing minds to life.; NY: Cambridge University Press, 1988.

[24] Yeung AS, Marsh HW, Suliman R. Can two tongues live in harmony: Analysis of the National Education Longitudinal Study of 1988 (NELS88) longitudinal data on the maintenance of home language. Am Educ Res J 2000; 37(4): 1001-26.

[25] Fuligini A. The academic achievement of adolescents from immigrant families: The roles of family background, attitudes, and behavior. Child Dev 1997; 68(2): 351-63.

[26] McLanahan S. Father absence and the welfare of children. In Hetherington M, Ed. Coping with Divorce, Single Parenting, and Remarriage: A Risk and Resiliency Perspective. Mahwah, NJ: Lawrence Erlbaum. 1999; 117-45.

[27] Portes A, Rumbaut R. A portrait of immigrant America. $3^{\text {rd }}$ ed. Berkeley: University of California Press, 2006.

[28] Suárez-Orozco M, Suárez-Orozco C. Children of Immigration. Cambridge, MA: Harvard University Press, 2001.

[29] Tobin J, Kurban F. Children of immigrants in early childhood settings in five countries: A study of parent and staff beliefs. Children Crossing Borders. n.d. [cited 2008 February 25]. Available from: http://www.children crossingborders.org/france.html

[30] OECD. PISA 2003 Technical Report. 2005; Available from: www.oecd.org/pisa

[31] Cohan J. The American Institutes for Research (AIR). AM Statistical Software Beta Version 0.06.03. 2003 [cited 2007 June 1]. Available from: www.air.org

[32] Baron R, Kenney D. The moderator-mediator variable distinction in social psychological research: Conceptual, strategic and statistical considerations. J Pers Soc Psychol 1986; 51(6): 1173-82.

[33] Eurydice. Integrating immigrant children into schools in Europe. 2004 [cited 2008 March 11]. Available from: http://www.eury dice.org

[34] Rumbaut R. Divergent Destinies: Acculturation, Social Mobility and Adult Transitions among Children of Latin American and Asian Immigrants. Paper presented at the biennial meeting of the Society for Research in Adolescence. Chicago IL. March 2008.

[35] Hernandez D. Demographic change and the life circumstances of immigrant families. Future Child 2004; 14(2): 17-47.

[36] de Cohen CC, Deterding N, Clewell BC. Who's left behind? Immigrant children in high and low LEP schools. Program for Evaluation and Equity Research. Washington, DC: The Urban Institute, September 2005 